\title{
PHENOLOGY OF Anacardium occidentale (ANACARDIACEAE) AND RELATIONSHIP WITH CLIMATIC FACTORS
}

\author{
Patrícia Oliveira da Silva ${ }^{1 *}$, Gisele Cristina de Oliveira Menino ${ }^{1}$, Paula Reys², Janailson Leônidas de Sá ${ }^{1}$, \\ Michellia Pereira Soares ${ }^{3}$, Fabiano Guimarães Silva ${ }^{1}$ \\ ${ }^{1}$ Instituto Federal Goiano, Campus Rio Verde, Rio Verde, Goiás, Brasil - patyoliveira1919@ @otmail.com*; gisele.menino@ifgoiano.edu.br; \\ janleonb13@hotmail.com; fabianoifgoiano@gmail.com \\ 2Universidade de Rio Verde, Rio Verde, Goiás, Brasil - preys@ hotmail.com \\ ${ }^{3}$ Instituto Federal do Norte de Minas Gerais, Campus Salinas, Salinas, Minas Gerais, Brasil - michelliabot@gmail.com
}

Received for publication: 13/11/2017 - Accepted for publication: 16/05/2018

\begin{abstract}
Anacardium occidentale (Anacardiaceae) is a species of great economic importance for Brazil and several other countries due to its food and medicinal uses. However, studies describing its reproductive phenological cycle are scarce. For this reason, this study aimed to describe the reproductive phenology of $A$. occidentale in Montes Claros de Goiás, state of Goiás, Brazil. Between June 2012 and July 2015, the phenophases of flower budding, anthesis, underripe fruit and ripe fruit were recorded monthly using the Fournier scale. Data were analyzed using the Fournier index, absence/presence method, and circular statistics. The data were correlated with the average, maximum, and minimum temperatures and the precipitation of the study area. Flowering and fruiting were synchronous in the dry season, and the two events ended with the onset of rainfall, resulting in a significant negative correlation between flowering and precipitation $(\mathrm{rs}=-0.73)$ and a significant positive correlation between fruiting and average temperature $(\mathrm{rs}=0.70)$ and between fruiting and maximum temperature $(\mathrm{rs}=0.41)$. The minimum temperature influenced when anthesis $(\mathrm{rs}=-0.64)$ and underripe fruit ( $\mathrm{rs}=-0.37$ ) would occur. The reproductive phenological events of $A$. occidentale are closely related to the climatic data of the studied area. A. occidentale presents reproductive strategies for species perpetuation in the study area.

Keywords: Cashew, flowering, observations, reproduction, seasonality.
\end{abstract}

\section{Resumo}

Fenologia de Anacardium occidentale (Anacardiaceae) e sua relação com os fatores climáticos. Anacardium occidentale (Anacardiaceae) é uma espécie de grande importância econômica para o Brasil e vários outros países por seu uso alimentício e medicinal. No entanto, estudos descrevendo seu ciclo fenológico reprodutivo são escassos. Nesse sentido, este estudo buscou descrever a fenologia reprodutiva de A. occidentale em Montes Claros de Goiás, estado de Goiás, Brasil. Entre junho de 2012 e julho de 2015, as fenofases botão, antese, pseudofruto imaturo e maduro foram registradas mensalmente utilizando a escala de Fournier. Os dados foram analisados utilizando o índice de Fournier, método de ausência/presença e estatística circular. Os dados ainda foram correlacionados com a temperatura média, máxima, mínima e precipitação da área de estudo. A floração e a frutificação foram sincrônicas na estação seca e os dois eventos encerraram com o início das chuvas, resultando em uma correlação significativamente negativa entre floração e precipitação ( $r s=-0,73)$, positiva entre frutificação e temperatura média $(r s=0,70)$ e temperatura máxima $(\mathrm{rs}=0,41)$. A temperatura mínima influenciou negativamente os eventos de antese ( $\mathrm{rs}=-0,64)$ e fruto imaturo ( $r s=-0,37$ ). Os eventos fenológicos reprodutivos de A. occidentale estão intimamente relacionados aos dados climáticos na área estudada. A. occidentale apresenta estratégias ecológicas reprodutivas para perpetuação da espécie na área de estudo.

Palavras-chave: Caju, floração, observações, reprodução, sazonalidade.

\section{INTRODUCTION}

The Cerrado is the second largest biome in Brazil (AGUIAR et al., 2016) after the Amazon. Its vegetation has developed different phenological strategies over thousands of years to withstand and survive a number of factors, including climate seasonality, low soil fertility, naturally occurring fires, and the activity of pollinators, dispersers and herbivores. Among these factors, seasonality has the greatest influence on phenological strategies since it controls the timing, intensity, duration, and frequency of factors affecting vegetative and reproductive phenological events (NOGUEIRA et al., 2013). 
Woody species generally have strategies that enable them to overcome seasonal water stress. In regions where the dry season is mild, fruiting is concentrated at the end of the rainy season, whereas fruiting occurs at the beginning of the dry season in regions where the dry season is more severe (FRANKIE et al., 1974). In regions with a moderate dry season, fruiting peaks occur in both the rainy and dry seasons. Additionally, in Cerrado areas with well-defined dry and rainy seasons, flowering is more common in the dry season.

Among the species of the Cerrado, Anacardium occidentale L. stands out. This tropical species is from the family Anacardiaceae (MATOS et al., 2014), commonly known as cashew, and occurs principally in the Northeast Brazil (DE CARVALHO NILO BITU et al., 2015) but is also found at lower densities in the Midwest region. According to Agostini-Costa et al. (2006), its pseudofruits are well accepted by the local population due to their exotic appearance and nutritional quality and are consumed fresh or as processed products. In addition, the species still presents several medicinal uses, such as its anti-inflammatory, astringent, antidiarrheal, antiasthmatic, depurative and tonic properties, and may act in the fight against diabetes (YUSUF et al., 2009; JAISWAL et al., 2016). All the organs of $A$. occidentale are useful, from the leaf and stem bark (YUSUF et al., 2009) to the fruits and pseudofruits. A. occidentale is native to Brazil but has been cultivated and used medicinally in several other countries, such as some African countries (YUSUF et al., 2009), Malaysia and India (JAISWAL et al., 2016).

The cashew agroindustry has a great socioeconomic impact in the Northeast region of Brazil due to the large number of income-generating jobs it creates in agricultural, industrial, and commercial activities. For the enrichment of local foods, it is a rich source of vitamin C, fiber, and antioxidants. The sustainable exploitation of native cashews of the Cerrado can also improve the quality of life of rural people, especially in t poorer areas of the Central-West region of Brazil (AGOSTINI-COSTA et al., 2006). However, the rapid deterioration of the cashew peduncle is a problem that requires great attention in order to find alternatives that may be used in the field and in the industry. A. occidentale peduncles for in-nature consumption are collected after development, at which point they have a firm texture and typical coloring (AGOSTINI-COSTA et al., 2006). However, the maturation time of the fruits depends on the climatic factors of each region since this species requires certain conditions for higher productivity.

According to Agostini-Costa et al. (2006), most of the cashew orchards are planted under a rainfed regime. However, the cashew tree tolerates a wide range of precipitation between $500 \mathrm{~mm}$ and 4,000 mm of rain per year. A dry period is important during the phases of flowering and fruiting since the high humidity favors fungal diseases. Very high humidity combined with high temperatures favors the action of fungi, which greatly damages the otherwise flourishing plants; indexes below 50\% during flushing for prolonged periods of time can compromise viability of the pollen. For fruiting to occur, the cashew needs intense sunshine evenly distributed over the canopy (AGOSTINI-COSTA et al., 2006). Thus, it is extremely important to follow the reproductive phenology of $A$. occidentale and to correlate the intensities and activity of these events with the climatic data of the area where this species is found.

Phenology represents an important aspect of the functioning of plant communities since its rhythm allows for predictions about primary productivity and food availability for fauna throughout the year (OLIVEIRA, 2008) and since it contributes to the understanding of the composition and distribution of species in plant communities. In addition, from an understanding of phenology, many other studies involving reproductive biology, the collection of fruits and seeds, and the dispersal of diaspores can be developed (SOUZA et al., 2014). In addition, the various results of phenological studies may aid in the production of agroforestry crops, pest control, recovery of degraded areas and management of beekeeping, resulting in the creation of jobs that target some plant product, the collection of fruits and seeds, or competition among plants for resources or pollinators (NEVES et al., 2010). In this way, the emergence of information regarding the development of cashew plants, including the determination of the meteorological parameters effects on the time of maturation of fruits in orchards in the Cerrado, is important because it will encourage and create perspectives related to management strategies, which will then make possible to match production to the requirements of the markets for in-nature consumption and agroindustry (MATOS et al., 2014). However, studies that address the reproductive phenology of $A$. occidentale in the Midwest region of Brazil are scarce.

Due to the limited knowledge about the phenology of A. occidentale, this study aimed to characterize and describe the reproductive phenology of a population of A. occidentale in Montes Claros de Goiás, state of Goiás, Brazil, in order to determine how the climatic factors (average, maximum, and minimum temperature and precipitation) of the study area influence its reproductive phenology and whether the events studied are seasonal. 


\section{MATERIAL AND METHODS}

The study was conducted in a Cerrado located in Montes Claros de Goiás $\left(16^{\circ} 08^{\prime} 89^{\prime} \mathrm{S}\right.$ and $51^{\circ} 18^{\prime} 63^{\prime}$ W, at an elevation of approximately $392 \mathrm{~m}$ ), Northwest Goiás, Brazil. The area, composed of veredas, cerradão, parks, cerrado and cerrado rock, presents complex vegetation that is both abundant and diverse. The Anacardiaceae family is among the ten best-represented families in terms of species in the study area (SOARES et al., 2015). The soil is considered a dystrophic latosol with a texture varying between medium and clayey, a pH of 5.4 , a base saturation of $22.89 \%$, a phosphorus content of $3.28 \mathrm{mg} / \mathrm{dm}^{3}$, a potassium content of $105.16 \mathrm{mg} / \mathrm{dm}^{3}$, and $0.42 \mathrm{cmol} / \mathrm{dm}^{3}$ of aluminum (SOARES et al., 2015). In the study area, in addition to the remaining vegetation, there are pastures used for dairy farming, some of which are abandoned.

The climate in the region is tropical (Aw) (ALVARES et al., 2013) with two well defined seasons, one drought that corresponds to the period from April to September and another rainy season that corresponds to the period from October to March. The climatic data of temperature $\left({ }^{\circ} \mathrm{C}\right)$ and precipitation $(\mathrm{mm})$ were taken from Climatempo (2016) for climatic characterization of the area and correlation with reproductive phenological data. The rainiest months, considering the average rainfall over the last 30 years (1985-2015) in the region (CLIMATEMPO, 2016), were December, January, February, and March (Figure 1). The driest months were June, July, and August. The minimum temperature varied from 18 to $24{ }^{\circ} \mathrm{C}$, the average from 24 to $30{ }^{\circ} \mathrm{C}$ and the maximum from 29 to $37^{\circ} \mathrm{C}$. May, June and July were the coldest months, while the hottest were September and October (Figure 1).

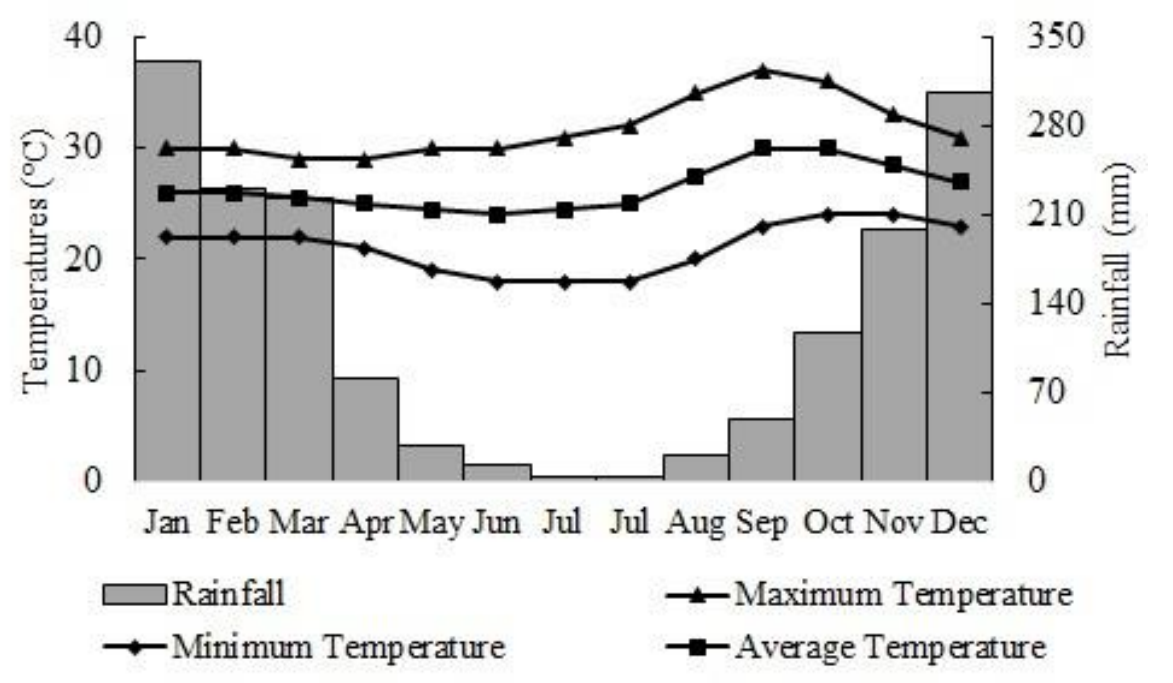

Figure 1. Climatic variation of Montes Claros de Goiás, state of Goiás, Brazil. Monthly averages of precipitation $(\mathrm{mm})$ and maximum, minimum and average temperatures $\left({ }^{\circ} \mathrm{C}\right)$ based on records from the last 30 years (1985-2015) (CLIMATEMPO, 2016).

Figura 1. Variação climática de Montes Claros de Goiás, estado de Goiás. Médias mensais de precipitação (mm), temperaturas máximas, mínimas e médias $\left({ }^{\circ} \mathrm{C}\right)$ dos últimos 30 anos (1985-2015) de registros (CLIMATEMPO, 2016).

The A. occidentale trees marked for the phenological study are part of the remaining vegetation of the study area; they are not part of a plantation constituting an orchard, as in the Northeast region of the country. Thus, the age of the plants varies, as do the stem diameter and height. Due to this, the density of the species in the study area is considered low.

Due to the low density of the species in the study area, only twenty plants of $A$. occidentale were chosen. The criteria for choosing trees were an apparent absence of diseases and infestations by parasites, a diameter at chest height of $10 \mathrm{~cm}$ and a fully visible crown (NOGUEIRA et al., 2013). All the plants marked had already reached reproductive age. The trees selected for the study were distributed along a $10 \mathrm{~km}$ stretch, marked with sequentially numbered plates and identified with the help of specific literature. A voucher specimen (registration number 389) was deposited in the Rio Verde Herbarium of the Federal Institute of Goiano (IFGoiano), Rio Verde, state of Goiás, Brazil.

Phenological events were recorded monthly between June 2012 and July 2015, totaling 38 months of observations. The events studied were the following reproductive phenophases: flower budding, anthesis (flower 
fully open), underripe fruit (pseudofruits) and ripe fruit (pseudofruits). The fruit was considered mature when it was completely yellow/red in color. Data collection was performed using the Fournier intensity index, composed of a semiquantitative five-point scale (0-4) that measures the intensity of each event individually as follows: absence of the phenophase (0); $1-25 \%$ (1); 26-50\% (2); $51-75 \%$ (3); and 76-100\% (4). These data were used to calculate the intensity index of each phenophase in each month, according to the formula proposed by Fournier (Equation 1):

$$
\mathrm{I}=\left[\left(\sum \mathrm{i} / 4 \mathrm{n}\right) \times 100\right]
$$

In which: I: intensity index of a given phenophase; $\Sigma \mathrm{i}$ : sum of the intensity indices of each tree sampled; and $\mathrm{n}$ : number of trees sampled.

The event synchrony was measured monthly by the presence or absence of each phenophase. After the percentage of each event was calculated, they were each classified as: an asynchronous event $(<20 \%$ of plants exhibit the event); (20-60\%) and a highly synchronous event (> 60\%) (BENCKE; MORELLATO, 2002).

To test the occurrence of intensity peaks of each phenophase, circular statistical analysis was applied using the Rayleigh test. This same method was used to calculate the length of the mean vector $r$, which is a measure of the concentration of the phenophase around the mean angle ranging from 0 to 1 , in which 0 indicates total uniformity of the observations and 1 indicates total concentration of the observations in or around the middle angle. The Rayleigh test indicates whether phenological events are homogeneously or evenly distributed during the study period or concentrated in a few months (peak); if the data are continuously distributed, there is no seasonality. The data were considered significant when $\mathrm{p} \leq 0.01$. The circular analysis was performed using Oriana 4.1 software (Kovach Computing Services, Isle of Anglesey, UK).

To evaluate whether the climatic data (average, maximum, and minimum temperature and precipitation) of the study area influence the phenophases, the climatic data were correlated with the phenological events. The climatic data of Montes Claros de Goias were acquired from Climatempo (2016). For the correlation, Spearman's correlation ( $r s$ ) was used. The data were considered significant when $\mathrm{p} \leq 0.05$. It was not possible to correlate the phenological data with other climatic data (photoperiod, relative air humidity, and wind speed) due to the absence of records for these variables in the study area.

\section{RESULTS}

The A. occidentale population evaluated in Montes Claros de Goiás displayed annual flowering with one flowering cycle each year. Flower budding and flower emergence began in the dry season, specifically in May, and continued through the first month of the rainy season in October (Figure 2A). The highest intensities were recorded in the study area between May $\left(19^{\circ} \mathrm{C}\right)$ and August $\left(20^{\circ} \mathrm{C}\right)$, the months considered the coldest and with low amounts of rainfall totaling $28 \mathrm{~mm}$ and $15 \mathrm{~mm}$, respectively (Figure 1).

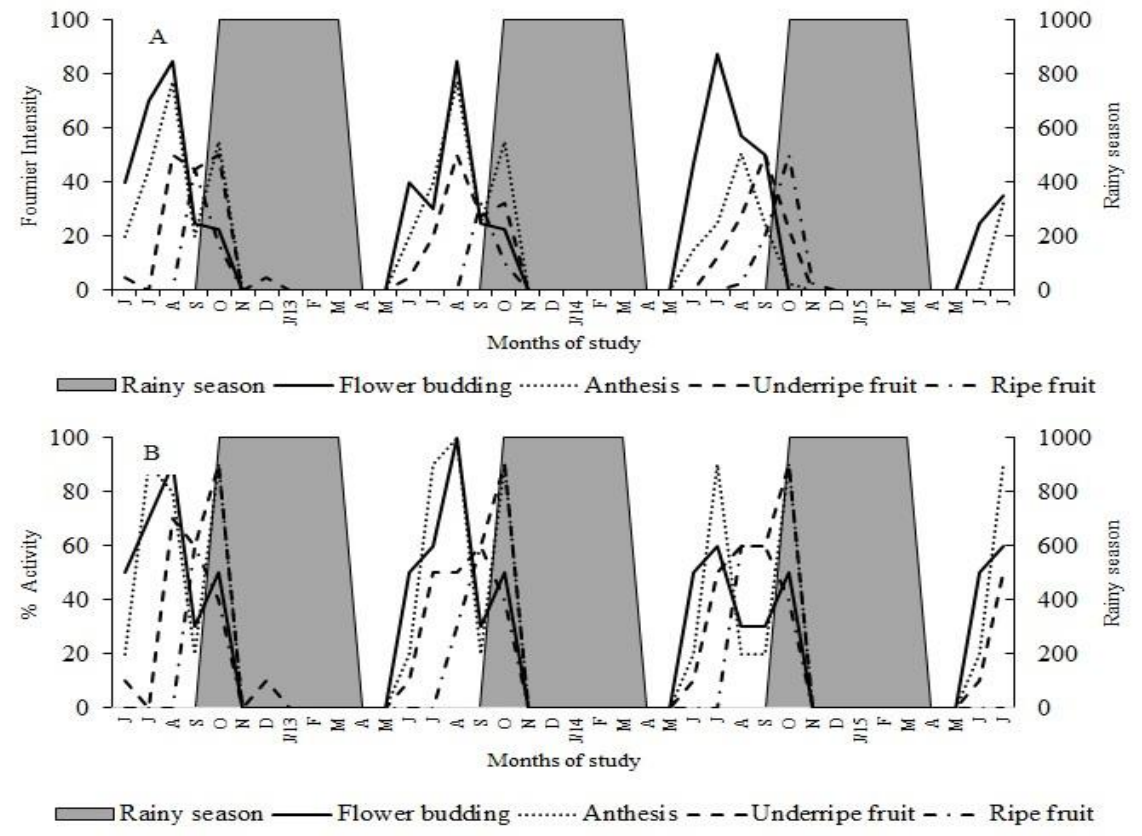


Figure 2. (A) Intensity and (B) synchrony of reproductive phenological events of Anacardium occidentale in Montes Claros de Goiás from June 2012 to July 2015. The (secondary) y-axis represents the rainy season (gray area corresponds to the months composing the rainy season in the study area).

Figura 2. (A) Intensidade e (B) sincronia de eventos fenológicos reprodutivos de Anacardium occidentale. Montes Claros de Goiás, junho de 2012 a julho de 2015. Eixo y (secundário) representa a estação chuvosa (área cinza corresponde aos meses que compreende a estação chuvosa na área de estudo).

The peaks of the flower budding and flowering phenophases were significantly seasonal with mean dates in August and September, respectively (Table 2). The events were highly synchronous in July and August, the months with the lowest rainfall of $3 \mathrm{~mm}$ and $15 \mathrm{~mm}$, respectively, in the two years of observation (Figure 2B). The flower budding and anthesis phenophases were reduced in terms of both intensity and synchrony with the beginning of the rainy season, resulting in a significant negative correlation between rain and flower budding ( $\mathrm{rs}=-0.80$ ), maximum temperature and budding ( $\mathrm{rs}=-0.43$ for intensity, $\mathrm{rs}=-0.44$ for synchrony), minimum temperature and budding ( $\mathrm{rs}=-0.77$ ), precipitation and anthesis ( $\mathrm{rs}=-0.73$ for intensity and $\mathrm{rs}=-0.74$ for synchrony) and minimum temperature and anthesis ( $\mathrm{rs}=-0.64$ for intensity and $\mathrm{rs}=-0.70$ for synchrony) (Table 1).

Table 1. Spearman correlation (rs) coefficients for the intensity and synchrony of reproductive phenological events of Anacardium occidentale and climate variables (average, maximum, and minimum temperature and precipitation).

Tabela 1. Coeficientes de correlação Spearman (rs) para a intensidade e sincronia de eventos fenológicos reprodutivos de Anacardium occidentale e variáveis climáticas (temperatura média, máxima, mínima e precipitação).

\begin{tabular}{lllll|cccc}
\hline & \multicolumn{3}{c}{$\begin{array}{c}\text { Correlation (rs) } \\
\text { Intensity }\end{array}$} & \multicolumn{3}{c}{$\begin{array}{c}\text { Correlation (rs) } \\
\text { Synchrony }\end{array}$} \\
\hline Phenophase & Aver. T & Max. T & $\begin{array}{c}\text { Med. } \\
\text { T }\end{array}$ & Rainfall & Aver. T & Max. T & Med. T & $\begin{array}{c}\text { Rainfa } \\
\text { ll }\end{array}$ \\
\hline $\begin{array}{l}\text { Flower } \\
\text { budding }\end{array}$ & 0.15 & $-0.43^{*}$ & -0.80 & $-0.81^{*}$ & 0.20 & $-0.44^{*}$ & $-0.77^{*}$ & $-0.80^{*}$ \\
$\begin{array}{l}\text { Anthesis } \\
\text { Underripe }\end{array}$ & 0.38 & -0.23 & $-0.64^{*}$ & $-0.73^{*}$ & 0.33 & -0.32 & $-0.70^{*}$ & $-0.74^{*}$ \\
$\begin{array}{l}\text { fruit } \\
\text { Ripe fruit }\end{array}$ & 0.65 & 0.07 & $-0.37^{*}$ & $-0.58^{*}$ & $0.66^{*}$ & -0.05 & $-0.51^{*}$ & $-0.51^{*}$ \\
\hline
\end{tabular}

*= significant at the 0.05 level of probability

Pseudofruit production was also annual and began in June, along with flowering, and continued through October. The peak of underripe fruit for A. occidentale was significantly seasonal (Table 2) with an average date in late September and early October, the hottest months in the study area, with temperatures of $37^{\circ} \mathrm{C}$ and $36^{\circ} \mathrm{C}$, respectively. The event was highly synchronous between August and October, the transition months between the dry and wet seasons, for both years of observation (Figure 2B). Pseudofruit production was lower compared to bud and flower production in the two years of observation (Figure 2B). On the one hand, the occurrence of underripe fruits correlated negatively and significantly with precipitation in terms of both intensity $(\mathrm{rs}=-0.80)$ and synchrony ( $\mathrm{rs}=-0.51$ ) (Table 1 ), because the event ended with the onset of the rains. On the other hand, there was a significant positive correlation between pseudofruit synchrony and average temperature $(\mathrm{rs}=0.66)$ and a negative correlation between pseudofruit synchrony and minimum temperature ( $\mathrm{rs}=-0.37$ for intensity and rs $=-0.51$ for synchrony).

Pseudofruit ripening began in September of the first year and in August of the second year and continued through October in both years (Figure 2A); September and August were the months with the highest temperature in the study area, with temperatures of $37^{\circ} \mathrm{C}$ and $36^{\circ} \mathrm{C}$, respectively. The peak of ripe fruit was also significantly seasonal, with an average date in October (Table 2). In addition, fruit ripening was highly synchronous in September.

Table 2. Circular statistics for the reproductive phenology study of A. occidentale conducted in Montes Claros de Goiás, state of Goiás, Brazil. Rayleigh test significant at $\mathrm{p}<0.01$.

Tabela 2. Estatísticas circulares para o estudo fenológico reprodutivo de A. occidentale realizado em Montes Claros de Goiás, estado de Goiás. Teste de Rayleigh significativo em p $<0.01$. 


\begin{tabular}{lcclc}
\hline \multicolumn{5}{c}{ Circular statistics } \\
\hline Phenophase & MVA & CSD & MVLr & Rayleigh test (p) \\
Flower budding & 234.95 & 39.92 & 0.78 & $<0.0001$ \\
Anthesis & 246.35 & 41.19 & 0.77 & $<0.0001$ \\
Underripe fruit & 272.88 & 35.15 & 0.83 & $<0.0001$ \\
Ripe fruit & 281.93 & 14.77 & 0.96 & $<0.0001$ \\
\hline
\end{tabular}

MVA: mean vector angle; CSD: circular standard deviation; $\mathrm{MVL}_{\mathrm{r}}$ : mean vector length.

The intensity and synchrony of the ripe fruit phenophase correlated positively and significantly with the average temperature ( $\mathrm{rs}=0.70$ for intensity and $\mathrm{rs}=0.76$ for synchrony) and with the maximum temperature (rs $=0.41$ for intensity and $\mathrm{rs}=0.39$ for synchrony) (Table 1 ).

All the reproductive phenological events of $A$. occidentale were concentrated in a certain period of time with high coefficients, which means that all the studied events were seasonal (Table 2). The event that presented the highest coefficient, indicating greater seasonality, was the phenophase of mature pseudofruit, which was the event that also had the shortest duration.

\section{DISCUSSION}

The flowering of A. occidentale occurred during the period of greatest water stress, indicating that the species presents a reproductive ecological strategy for the perpetuation of the species in the area. In fact, flowering in the dry season is favorable to some extent, whereas in the rainy season, nectar is diluted, reducing the attractiveness of flowers to different pollinators. In addition, flowering that is concentrated in the dry season or in the transition between the dry and rainy seasons is an indication that the reproduction of woody species in the Cerrado is not limited by the reduced availability of water during this period, because they have mechanisms that promote their survival and reproduction during dry periods (BATALHA; MANTOVANI, 2000). In addition, plants under stress tend to advance their reproductive cycle so that, in case the individual cannot persist in that situation, there is at least a chance of perpetuating the species through the descendants left by that individual.

The period in which the trees of $A$. occidentale flowered, in addition to being the one with the highest water stress, are the ones that presents the lowest temperatures according to the climatic data of the studied area. Agostini-Costa et al. (2006) corroborate that the high humidity associated with high temperatures favors fungal action, which is detrimental to flowering, as loang as a humidity rates of less than $50 \%$ for prolonged periods during flowering can reduce the viability of pollen. Thus, this seems to be the most appropriate period for the flowering of $A$. occidentale, not only for this species but several other species of the same family (Anacardiaceae), such as A. humile, A. nanum (AGOSTINI-COSTA et al., 20006) and Astronium fraxinifolium (PIRANI et al., 2009; ASSUNÇÃO et al., 2014) thatflower during a similar period as the ones studied here.

Rainfall has been shown to inhibit reproductive events such as flowering and fruiting (PIRANI et al., 2009). The negative correlation between rainfall and flowering can be explained by the fact that flower structures in species with tiny, delicate flowers can be damaged by the heavy rains of tropical forests. According to Pirani et al. (2009), phenological cycles can be adjusted due to competition between pollinators and seed dispersers, which depend on the resources provided by plants. Thus, it appears that A. occidentale trees have adjusted their flowering time to prevent damage to flowers and to increase visitation by pollinators, which are more abundant in the dry season. Nevertheless, other factors affect flowering time in cashew trees, and according to Almeida et al. (2002), this phenophase is directly related to the low cloud cover and high solar radiation that occur in the period of greatest water stress.

For zoochorous species such as A. occidentale, the rainy season is the most suitable period for fruit development, especially that of fleshy fruits, and for seed dispersal. Nevertheless, woody species of the Cerrado such as Annona coriacea (SOARES et al., 2013) and Byrsonima basiloba (SILVA et al., 2016) are able to fruit in the dry season due to the availability of water in the soil profile. Additionally, fruiting in the dry season has been linked to reduced competition for dispersers. This behavior can be considered another ecological strategy of A. occidentale since one of the biotic factors most strongly related to reproductive phenological events is dispersal (NEVES et al., 2010).

The low fruit set of $A$. occidentale may be explained by the fact that not all flowers are pollinated, resulting in low fruit yields despite the large numbers of flowers. However, other factors may determine the falling of reproductive structures before they are fully developed. Strong winds could cause the falling of flowers 
and fruits at early stages of development. Moreover, according to Ribeiro (2009), extremely low temperatures during flowering and fruiting of cashew trees can cause damage, including fruit abortion and flower dropping, whereas extremely high temperatures can also affect fruit yield due to flower wilting and young fruit dropping. A temperature of 18 to $35{ }^{\circ} \mathrm{C}$ is required for normal fruit development in cashew trees (RIBEIRO, 2009), but the temperatures in the study area reached $37^{\circ} \mathrm{C}$ (Figure 1), which may have caused damage to flowers and developing fruits.

Other studies have reported a negative association between rainfall and fruiting. Fioravanço et al. (2012) found a negative correlation between rainfall and fruiting in apples and reported that the rains caused the falling of flowers and fruit and reduced effective fruiting by damaging the fruit epidermis, reducing fruit sizeand increasing the percentage of rotten fruit. Pirani et al. (2009) found a similar correlation for several species in the Cerrado of Mato Grosso, Midwest Brazil. The occurrence of a well-defined dry season for 5 to 6 months is one of the main favorable climatic conditions for fruit production in the Cerrado. Moreover, cashew crops require between 800 and 1,500 mm of rainfall distributed over five to seven months of the year (OLIVEIRA, 2002). Even though, according to Agostini-costa et al. (2006), the species tolerates precipitation below and above (between $500 \mathrm{~mm}$ and $4,000 \mathrm{~mm}$ ) that range, higher precipitation values increase relative humidity above $65 \%$, resulting in a higher incidence of fungal diseases such as anthracnose, powdery mildew, and sooty mold.

A. occidentale displayed a fruiting pattern similar to that of anemochorous species because dispersal of anemochorous diaspores is favored during drier periods in regions with a seasonal climate and because the low relative humidity promotes fruit opening. However, A. occidentale is zoochorous, and the increase in wind speed during the dry season reduces canopy cover, making the fruits more visible and improving dispersal (OLIVEIRA, 2008). Thus, this can be considered another reproductive strategy to maximize reproductive success, since the synchrony of fruit ripening is evidence that the ripening period has been evolutionarily adjusted to match the availability of dispersers and the occurrence of favorable conditions for germination.

Similarly, Morellato et al. (1989) showed that species that produces fruits at the end of the dry season have ripe fruits at the beginning or in the middle of the rainy season, which increases the chances of seed germination and seedling establishment because seeds benefit not only from water but also from the nutrients released by the decomposition of organic matter accumulated during the dry season. According to Pirani et al. (2009), seedlings that emerge at the beginning of the rainy season find conditions favorable for establishment, because they can develop deep root systems ahead of the next dry season. Thus, the reproductive phenology of plants that grow in seasonal habitats has been shaped to match the ripening of fruits and dispersal of seeds to more favorable times for seedling survival and growth.

Temperature was an important factor in the development and ripening of A. occidentale fruits. Senshan et al. (1995) showed that Midwest Brazil experiences greater variation in air temperature during the dry season, which has a significant effect on the time required for the development and ripening of cashew fruits. Matos et al. (2014) found that higher average temperatures reduced ripening time in dwarf cashew, which is likely explained because dwarf cashew is a tropical species requiring a temperature of approximately $27^{\circ} \mathrm{C}$ for optimal development (ALMEIDA et al., 2002). In addition, a ripening time of $\sim 36$ days was recorded in months with mean temperatures $\geq 28{ }^{\circ} \mathrm{C}$ (MATOS et al., 2014). These findings indicate that cashew species have adjusted their ripening time to match periods of higher temperatures so that fruits are fully developed and dispersed in the rainy season.

The final maturation stage of cashew is characterized by a change in the color of the pseudofruit from chestnut gray to yellow or red (according to the cultivar), a change in the texture of the pseudofruit and a change in the ease of detachment when touched. For this reason, one of the major causes of production losses, mainly for in-nature consumption, is the pseudofruit falling on the soil. Thus, mature pseudofruits, which are detached easily from the mother plant, should be collected immediately (MATOS et al., 2014).

\section{CONCLUSION}

- Precipitation negatively influences when the phases of flower budding, anthesis and underripe fruits occur in A. occidentale, while the average and maximum temperatures positively influence when the phases of underripe and ripe fruits occur in the studied area. In addition, the minimum temperature negatively influences when the phases of flower budding and anthesis occur.

- The reproductive phenological cycle of the species was adjusted to the environmental conditions of the studied area, as such, A. occidentale presents ecological reproductive strategies for the perpetuation of the species in the studied area. Further, all the events studied are seasonal.

- The low productivity of A. occidentale explains the low density of the species trees found in the study area.

FLORESTA, Curitiba, PR, v. 49, n. 1, p. 069-078, jan/mar. 2019

Silva. P. O. et.al.

ISSN eletrônico 1982-4688 
- With a defined period for fruiting, the plants who collect cashew fruits should pay attention to the maturation period of the pseudofruits to avoid the collection of damaged fruits, thus avoiding the waste of time and unnecessary expenses.

\section{ACKNOWLEDGMENTS}

The authors thank the Coordination for the Improvement of Higher Education Personnel (CAPES) and the Federal Institute of Goiano (IFGoiano), Rio Verde.

\section{REFERENCES}

AGOSTINI-COSTA, T.S.; FARIA, J.P.; NAVES, R.V.; VIEIRA, R.F. Cajus do Cerrado. In: VIEIRA, R.F.; COSTA, T.S.A.; SILVA, D.B.; SANO, S.M.; FERREIRA, F.R. (Ed.) Frutas nativas da região Centro-Oeste do Brasil, Ed. Embrapa Recursos Genéticos e Biotecnologia. 2006, 320p.

AGUIAR, S.; SANTOS, I.S.; ARÊDES, N.; SILVA, S. Redes-bioma: informação e comunicação para ação sociopolítica em ecorregiões. Ambiente \& Sociedade, São Paulo, v. 19, n. 3, p. 233-252, 2016.

ALMEIDA, F.A.G.; JUNIOR, W.M.; ALMEIDA, F.C.G. Fenologia comparativa de dois clones enxertados de cajueiro anão em condições de irrigação. Ciência Rural, Santa Maria, v. 32, n. 2, p. 221-228, 2002.

ALVARES, C.A.; STAPE, J.L.; SENTELHAS, P.C.; GONÇALVES, J.L.M.; SPAROVEK, G. Köppen's climate classification map for Brazil. Meteorologische Zeitschrift, Alemanha, v. 22, n. 6, p. 711-728, 2013.

ASSUNÇÃO, V.A.; CASAGRANDE, J.C.; SARTORI, A.L.B. Floristics and Reproductive Phenology of Trees and Bushes in Central West Brazil. Anais da Academia Brasileira de Ciências, Rio de Janeiro, v. 86, n. 2, p. 785-799, 2014.

BENCKE, C.S.C.; MORELLATO, L.P.C. Estudo comparativo da fenologia de nove espécies arbóreas em três tipos de Floresta Atlântica no Sudeste do Brasil. Revista Brasileira de Botânica, São Paulo, v. 25, n. 2, p. 237$248,2002$.

CLIMATEMPO. Disponível em: http://www.climatempo.com.br/climatologia/4861/montesclarosdegoias-go. Acesso em: 15 out. 2016.

DE CARVALHO NILO BITU, V.; DE CARVALHO NILO BITU, V.; MATIAS, E. F.; DE LIMA, W.P.; DA COSTA PORTELO, A.; COUTINHO, H, D.; DE MENEZES, I, R. Ethnopharmacological study of plants sold for therapeutic purposes in public markets in Northeast Brazil. Journal of Ethnopharmacology, v. 172, n. 9584, p. 265-272, 2015.

FIORAVANÇO, J.C.; CZERMAINSKI, A.B.C.; ALVES, S.A.M. Condições meteorológicas e sua influência na safra de maçã de 2011/12 em Vacaria, RS. Comunicado Técnico 123, Bento Gonçalves. EMBRAPA. 2012, 8p.

FRANKIE, G.W.; BAKER, H.G.; OPLER, P.A. Comparative phenological studies of trees in tropical wet and dry forest in the lowlands of Costa Rica. Journal of Ecology, Londres, v. 62, n. 3, p. 881-919, 1974.

JAISWAL, Y.S.; TACKE, P.A.; GABHE, S.Y.; VAIDYA, A.B. Antidiabetic activity of extracts of Anacardium occidentale L. leaves on n-streptozotocin diabetic rats. Journal of Traditional and Complementary Medicine, v. 7, n. 4, p. 421-427, 2016.

MATOS, V.A.T.; PIVETTA, F.; PAIVA, SOBRINHO. S.P.; TISSIANI, A.S.O.; PEREIRA, A.P.M.; RAMOS, F.T.; CAMPELO JUNIOR, J.H. Temperaturas basais e exigência térmica para a maturação de caju. Bioscience Journal, Uberlândia, v. 30, n. 4, p. 969-977, 2014.

MORELLATO, L.P.C.; RODRIGUES, R.R.; LEITÃO FILHO, H.F.; JOLY, C.A. Estudo comparativo da fenologia de espécies arbóreas em floresta de altitude e floresta mesófila semidecídua na Serra do Japi, Jundiaí, São Paulo. Revista Brasileira de Botânica, São Paulo, v. 12, n. 1, p. 85-98, 1989.

NEVES, E. L.; FUNCH, L. S.; VIANA, B. F. Comportamento fenológico de três espécies de Jatropha (Euphorbiaceae) da Caatinga, semi-árido do Brasil. Revista Brasileira de Botânica, São Paulo, v. 33, n. 1, p. 155-166, 2010. 
NOGUEIRA, F.C.B.; PACHECO FILHO, A.J.S.; GALLÃO, M.I.; BEZERRA, A.M.E.; MEDEIROS FILHO. Fenologia de Dalbergia cearensis Ducke (Fabaceae) em um fragmento de floresta estacional, no semiárido do Nordeste, Brasil. Revista Árvore, Viçosa, v. 37, n. 4, p. 657-667, 2013.

OLIVEIRA, P.E. Fenologia e biologia reprodutiva das espécies de Cerrado. In: SANO SM, ALMEIDA SP, RIBEIRO JF. Cerrado: ecologia e flora. EMBRAPA. 2008, 408p.

OLIVEIRA, V.H. Cultivo do cajueiro anão precoce. Fortaleza: EMBRAPA. 2002, 40p.

PIRANI, F.R.; SANCHEZ, M.; PEDRONI, F. Fenologia de uma comunidade arbórea em Cerrado sentido restrito, Barra do Garças, MT, Brasil. Acta Botânica Brasílica, Belo Horizonte, v. 23, n. 4, p. 1096-1109, 2009.

RIBEIRO, J.L. Implantação e manejo da cultura do cajueiro-anão-precoce na região Meio-Norte do Brasil. EMBRAPA. 2009, 38p.

SENSHAN, Y.; LOGAN, J.; COFFEY, D.L. Mathematical formulae for calculating the base temperature for growing degree-days. Agricultural and Forest Meteorology, v. 74, n. 1, p. 61-74, 1995.

SILVA, P.O.; BALESTRA, C.L.; SOARES, M.P.; MENINO, G.C.O. Estratégias Fenológicas de Byrsonima basiloba em Rio Verde, Goiás. Pesquisa Florestal Brasileira, Colombo, v. 36, n. 87, p. 289-295, 2016. SOARES, M.P.; SILVA, P.O.; SÁ, J.L.; REYS, P.; DOURADO, D.M.; SANTOS, T.M. Fenologia de Annona coriacea Mart. (Annonaceae) em um Fragmento de Cerrado Sensu Stricto em Rio Verde, Goiás. Revista do Instituto Florestal, São Paulo, v. 25, n. 1, p. 107-113, 2013.

SOARES, M.P.; REYS, P.; PIFANO, D.S.; SA, J.L.; SILVA, P.O.; SANTOS, T.M.; SILVA, F.G. Relationship between Edaphic Factors and Vegetation in Savannas of the Brazilian Midwest Region. Revista Brasileira de Ciência do Solo, Viçosa, v. 39, n. 3, p. 821-829, 2015.

SOUZA, D.N.N.; CAMACHO, R.G.V.; MELO, J.I.M.; ROCHA, L.N.G.; SILVA, N.F. Estudo fenológico de espécies arbóreas nativas em uma unidade de conservação de caatinga no Estado do Rio Grande do Norte, Brasil. Biotemas, Santa Catarina, v. 27, n. 2, p. 31-42, 2014.

YUSUF, S.; ALIYU, M.; NDANUSA, R. Effect of aqueous extract of Anacardium occidentale (L) stem bark on sodium and chloride transport in the rabbit colon. Journal of Medicinal Plants Research, v. 3, n. 6, p. 493-497, 2009. 
FLORESTA, Curitiba, PR, v. 49, n. 1, p. 069-078, jan/mar. 2019 Silva. P. O. et.al. 